\title{
WHEN UNIVERSITY BECOMES THE ENEMY: HATE SPEECH ATTACKS ON FACEBOOK
}

\author{
VIVIANE DE MELO RESENDE ${ }^{1}$, YARA MARTINELLI ${ }^{2} \&$ ERNANI VIANA SARAIVA $^{3}$ \\ ${ }^{1}$ University of Brasilia, Department of Linguistics, Campus Darcy Ribeiro, ICC Sul, Mezanino, Instituto \\ de Letras, Gabinete 38 - Asa Norte, Brasilia, Brazil. ORCID: 0000-0002-7791-5757, Email: resende.v.me- \\ lo@gmail.com \\ ${ }^{2}$ University of Brasilia, Campus Darcy Ribeiro, ICC Sul, Mezanino, Edificio dos Institutos de Ciencias \\ Politicas e Relacoes Internacionais - Asa Norte, Brasilia, Brazil. ORCID: 0000-0002-4591-7328, Email: \\ yararmmartinelli@gmail.com \\ ${ }^{3}$ Fluminense Federal University, Departamento de Administracao - MDM, Av. Aluizio da Silva Gomes, \\ 50 - Granja dos Cavaleiros, Macae - RJ, 27930-560, Brazil. ORCID: 0000-0001-7548-6330, Email: ernan- \\ isaraiva@gmail.com
}

ABSTRACT: The extreme right hate speech propagated currently in Brazil addresses a broad social spectrum, from feminist movements to traditional communities. The academic community and higher education institutions are also targets, as they are identified as poles of democratic resistance. Specific hate speech towards academy in Brazil is the subject of this paper. The persecution of academic community and knowledge itself occurs through the discursive dispute especially on social networks, and thus in this analytical exercise, we looked up at Facebook's largest bolsonarista's group - the "Jair Bolsonaro Presidency Support Group", which brings together 317,000 members. We analyzed the memetic discourse on the page, focusing memes that were published between April and June 2019, thematizing higher public education, and presenting a bimodal verb-visual composition. These criteria led to the collection of 115 memes analyzed with the support of a QDA package. Analysis reveals the disqualification of university institutions and their actors through ironies, negative associations including stereotypes, simplification of debate to the shallower. Students are often associated with nudity as immorality, professors of indoctrination and ridicule, protesters of ignorance, or bad character. Political debate is reduced to extreme left-right 
polarization, with the criminalization of the left.

KEYWORDS: Critical Discourse Analysis, hate speech, ultra right, Facebook, Brazil

\section{INTRODUCTION}

Bolsonarismo is the actual name of the extreme right ideology propagated by Brazilian President Bolsonaro and his followers, named bolsonaristas. Its hate addresses to a broad social spectrum like women and feminist movements, racialized populations, indigenous peoples and traditional communities, LGBTQ + groups, impoverished populations living in marginalized territories, Afro-Brazilian religions practitioner, among others. The academic community and higher education institutions are also targets, as they are identified as poles of democratic resistance. This perception has raised since students and university professors organized national demonstrations after the announcement of resource cuts (euphemistically phrased as contingencies by official discourse) which made clear its ideological bias. Those hate speeches and the use of memes as a mass media penetration are the subject that we will address in this article.As part of the current management of Brazil's federal executive power policies, the financial resource cuts have been implemented in the area of education, which currently operates at a budget well below what is needed to maintain activities. Some Brazilian universities have already announced that with the resources available to them after the cuts, they will not be able to maintain their activities until the end of the year. The announcement of the resource cuts in April 2019, accompanied by the suspension of scholarships and other unpopular measures, especially for their markedly ideological justifications, provoked reactions, on the one hand from the academic community and, and on the other hand, as an offensive by conservative discursive forces.

We observed that the persecution of minority groups and of knowledge itself occurs in the form of public policies that deconstruct the hardly achieved progress made during the democratic period in Brazil - in the case of universities, the struggle over financing and autonomy - but also through the discursive dispute, especially on social networks. The head of the federal executive communicates with his electorate mainly through messages on Twitter, and the unconditional defense of the ideologies that underpin bolsonarismo is the input of groups that organize themselves on social networks, especially on Facebook.

In this analytical exercise, we looked up at Facebook's largest bolsonarista's group - the “Jair Bolsonaro Presidency Support Group”, which brings together 317,000 members. We analyzed the memetic discourse (Ferreira; Vasconcelos 2019) on the page, focusing only on memes that met the following criteria:

- they were published between April 28, 2019 (two days before the announcement of the cuts) and June 2, 2019 (two days after the second march against cuts in education resources);

- their theme was higher public education,

- Furthermore, they presented a bimodal verb-visual composition. 
These criteria led to the collection of 115 memes. The collected data were analyzed with the support of a QDA package.

\section{HATE SPEECH: CONSERVATIVE SPEECH STRATEGIES}

Anticommunism as the basis for hate speech and polarizing political forces, was renewed in Brazil from 2015, according to Kaysel (2018). In response to post-neoliberal governments in Latin America, post-democratic inflections against President Dilma Rousseff had one of its first acts in the 2016 World Coup in Brazil (Ballestrin 2018). The communist threat discourse has been central to conquer public support for undemocratic plans, with remarkable continuities from the Cold War period - so Kaysel (2018) insists that anti-communism is not just outdated, as shown on social networks, media, and congress. Historical anti-communism - from the cold war period - was based on the ideological matrices identified in Catholic religious' conservatism, nationalism, and liberalism. Kaysel explains that these conservative forces have been resignified to this hybrid war period in which democracies are forcibly overthrown by the force of discursive technologies in the political use of big data.

Religious conservatism - nationalism, which promotes identification between nation and a particular patriarchal and heteronormative family model - and economic liberalism with low democratic density are the same reorganizing matrices, now with pentecostal political force. Even if it is a significant void, a very vague threat, the broadening of the semantic scope of anti-communism becomes an agglutinating force, which is associated in chains of meaning with other senses, contrary to feminism, to the rights of the LGBTQ + population, to black movements, and to any claim to the enlargement of the democratic debate (Kaysel 2018).

For this reason, Luciana Ballestrin (2018) understands that the composition between political authoritarianism and economic ultra-liberalism is possible in the global South because here, liberalism was not accompanied by a real democracy. Here, what happened was an enslaver democracy, which has never been completely overcome. So, in Brazil, the de-democratization goes by non-humanism, by the denial of the other's humanity, since an ideology of dehumanization is necessary to legitimize barbarism (Barbosa 2018). In this sense, the hate speech currently intensified in Brazil redraws in new shades the ontological denial of the other that Fanon (2015) already spoke about, one of the aspects of coloniality.

Ballestrin (2018) defines this global wave of de-democratization and "autocratization" as a rightward turn with the rise of conservative discourses. For her, the genesis of fascist discourses lies in the breaches of liberal democratic discourses. Wondering how democratic debate can act against democracy, in favor of de-democratization, she finds answers in social networks. Since digital communication has become a daily practice in many societies, media has become the arena of sociability and social and political commitment (Lorenzo-Dus and Cristofaro 2016). Social media has assumed an essential role in Brazilian political communication, especially since the 2018 elections, and remains relevant for maintaining the polarization state in which the country has been since then. 
Radical political polarization is mainly based on hate speeches, "directed especially at minority groups" (Freitas; Castro 2013: 327). To these groups (minorized in terms of their accesses or the systematic persecution they suffer, which does not mean or need to mean demographic minority) are addressed words that offend, due to identity characteristics such as race, ethnicity, nationality, sexuality, etc., including even inciting violent actions (Brugger 2007). In this case, the hate speech is addressed not to minorities linked to race or sexuality, but to institutional (university) and political (especially the Workers' Party) belonging.

The scope of hate speech covers a broad spectrum of aggression, including harassment, degradation, devaluation, and dehumanization. This large amplitude is relevant for the functioning of these discourses to divide the groups that hate and those identified as a threat, based on the separation of "us" and "them" (Gagliardone et al. 2015). For Rita Segato (2018), the discourse of moral superiority that underlies the we-they opposition characterizes a significant detriment to humanity, by creating distinctive categories of the same humanity. Benesch (2012) is also concerned with the discursive signs that call for violence, such as characterizing the target of speeches as nonhuman (worms, animals) or resorting to the we-them opposition. This call is done by emphasizing the supposed risk they would pose to the speech audience (that is, to the group characterized as 'we'). Rosane Silva and her co-authors draw attention to the discursive resources used as the apparatus of hate speech: target group stereotypes, decontextualization of events, and creation of an enemy figure through fear and anger strategies (Silva et al. 2011). Through the written record of hate speech attacks, scandal perpetuation can be achieved (WALDRON 2010), and for that, social networks are handy tools.

\section{MEMETIC SPEECH AND POLITICAL POLARIZATION}

The origin of the term meme goes back to Dawkins's (2001) neo-Darwinian research. The author proposed an articulation between genetics and cultural studies, and in this perspective, he coined the term 'meme' related to 'gene' and 'mimesis' (Junqueira 2016: 21). Reproductive and perpetuation strategies of genes, in an approximation with the theories of evolution and natural selection, are transposed to culture, related to the perpetuation of practice or idea. According to Silva (2018: 4), the question is the "transmission of information that spreads from brain to brain through a process that can be, in a broad sense, called imitation".

Contemporary researches of memetic discourse keep in mind this fundamental understanding of the concept of the meme, comprehending memes as ideas propagated by imitation of patterns and content. As with genes, "memes in their propagation process are also subject to modifications - true mutations - that help to keep the idea alive and adapt" (Junqueira 2016: 21). Furthermore, this is how the meme differs from other replications of online products and ideas: throughout the going viral process, it is transformed and readjusted, gaining more strength. This competition for propagated ideas' perpetuation occurs, according to Dawkins (2001), for attention and retention in the human brain of the message that is transmitted. In the virtual 
environment, says Junqueira (2016: 21), it is mainly about "stimulus saturation, to which Internet users are constantly exposed, and that results in no longer processable amount of information". That is why the fixing strategies are so relevant.

Generally, memes are, in Andrea Silva's definition (2018: 4), messages or behaviors that replicate themselves indiscriminately and without indication of authorship. Thereby, these texts are generally multimodal, mobilizing groups that, in social networks, are engaged with the dissemination of information, with the ability to influence behaviors. The success of a meme, for the same author, depends on its content and appeal, influencing its capacity to relate to other memes already accepted and thus 'going viral'. Silva also argues that the replication of memes in the social networking environment is anchored mainly in three characteristics:

(i) Mutation - when the meme is changed as it is replicated by social network users;

(ii) Natural selection - not all memes remain active on the network and not all become viral;

(iii) Heredity - a meme as a variation and/or a combination of the original one (2018: 4-5).

Thanks to the speed and capillarity in social media (2017: 179), people are increasingly becoming informed about politics. In this environment: the vast amount of information, the speed, simplicity, and practicality of content - which is more imagetic and less written - and humor, which seems to bring relaxation to themes often thought of as inaccessible, may be reasons for this phenomenon. About this subject, Chagas et al. (2017: 178) point out that new forms of humor emerge from digital technologies, and "political humor on the Internet contributes to the creation and consolidation of a web of shared meanings that absorbs and resignifies popular culture content". Thereby, political content is constructed and shared on a large scale, using jokes as discursive strategies, and propagated as humorous messages, but carrying selected content, and of course, marked with intents.

Anyone connected to social media can be a meme's creator, transformer, or multiplier. These texts, which may be seen as only jokes, unpretentious and without impact, actually have great power: with their high ability to multiply, they spread virally and begin to shape political opinions, becoming part of the virtual environment. "About political memes, in general, in the specific context of Facebook, they have been marked by polarized clashes and fragile arguments" (Silva 2018: 9).

Initially, the possibility of transforming the content circulating seems positive and democratic; however, aligned with post-truth, fake news, and placed in a polarized political context, it can become dangerous. Because humor is exceptionally prominent, memes often gain a seemingly light and joking aspect - which masks the psychological threat of their impact, mainly when they act as a vehicle for hate speech.

When it comes to political content, this mix of humor and hate can become dangerous. The trivialization generates rapprochement and arouses interest - something that political discourses, texts, and content rarely cause. Thus, memes are becoming an authoritative new source of policy misinformation, acting as an instrument for trivializing political debate, and reinforcing hate speech. 


\section{BOLSONARISTS MEMES: THE UNIVERSITY AS THE ENEMY}

The discursive construction of an enemy, by the spreading of fear and hate, is one of the main strategies for controlling people's thoughts and practices, and for justifying political actions and decisions. A great example of this is the fascist's governments of the twentieth century, which, without exception, in order to justify their actions, built by propaganda the figure of a common enemy to be fought (Fausto 1998). This discourse has a unique chance of successfully propagating itself in crisis contexts: pointing an enemy to blame for the evils of the context in question can mobilize, successfully, thoughts, and practices.

Our current crisis context in Brazil includes the economic impacts of the international crisis of 2008, in a foreign market dependent country, added to the political crisis since 2013, solidly anchored in the interference of mass media and social media. In addition, conservative groups considered many public policies promoted by the Worker's Party outrageous. They saw gender, race, and sexuality on the agenda, and felt that these guidelines went directly against their religious and conservative perspectives, which have always permeated the Brazilian mentality - and that before were not openly questioned. Elites also found it challenging to cope with access policies, such as racial and social quotas, which restricted privileges that these classes understand as their rights.

For example, in the current Brazilian government program, we can see agendas as combating "the apology of gender ideology" and "privileges deriving from quotas". Those are examples of conservative proposals that represent regression towards inclusive measures of progressive governments, despised by the most conservative and religious sectors of society. Both arguments are associated with the academic environment and public universities in the current defamation campaign.

Attacks to the universities, science, and education on a broad scale are not fortuitous in Brazil's post-democratic regime. It is a strategy consistent with a particular nation project. The Brazilian president and his education minister have been attacking the scientific and academic community since April 2019, for example, when the president falsely stated that science in Brazil was centrally developed in private institutions. On April 8, 2019, Bolsonaro stated, in an interview to a radio station, "in universities, when we talk about research, you do not have nothing..., few universities have real research, and of those few, most are in private initiative". This is the opposite of reality: more than $90 \%$ of the Brazilian scientific work is carried out in public, federal, and state universities. According to a survey conducted by Clarivate Analytics for the Higher Education Personnel Improvement Coordination (CAPES), 95\% of all Brazilian scientific production is made by public universities - federal and state ones. According to the Leiden Ranking, "between the 20 universities that publish more in Brazil, there are no private ones". Available at http://ciencianarua.net/wp-content/ uploads/2019/04/Screen-Shot-2019-04-11-at-12.20.06.png. Accessed September 8, 2019.

About two weeks later, the newly appointed minister of education, Abraham Weintraub, in a video posted on Facebook, spoke out against public investment in human- 
ities researches areas, which he finds unhelpful to society. He took up the subject in his first press interview - he said that it is not "against studying philosophy", but this area of study should be restricted to those who can pay for it in private universities. The next day, the president said, on Twitter, that he was studying "decentralizing investment in areas as philosophy and sociology". According to him, he intended transferring resources to areas that "generate immediate taxpayer return", which he associated with agrarian and health sciences.

A few days later, his education minister declared that he would cut funds from universities promoting "shambles", in a direct attack on the University of Brasilia, the Fluminense Federal University and the Federal University of Bahia, not coincidentally strongholds of democratic resistance. Faced with the evident political motivation of the cuts, the same day the minister decided: he would cut $30 \%$ of the discretionary resources not only from those identified as non-submitable but also from all federal universities.

What followed was the organization of resistance in the form of national marches and demonstrations that gathered millions of people, summed up in the main cities of the country but also in small cities, in all regions of Brazil. The bolsonarist offensive was also organized in the form of memes that circulated in social networks and messaging applications, especially WhatsApp groups, which questioned the relevance of universities and built a negative image of these institutions, especially in the humanities and social areas. For example, many covers of monographs, dissertations, and theses on the LGBTQI+ theme began to circulate as a way of demoralizing, by conservative bias, the science produced in these areas of knowledge.

In May 2019, two significant marches took place in favor of education and universities. The first one was called even before the financial cuts, a standstill in defense of education and against social security reform that was boosted by the mobilization against cuts in investment in higher education. This demonstration, called \#15M, took place on May 15, bringing together over 1 million people in more than 200 cities in 26 Brazilian states and the Federal District. Regarding this demonstration, Bolsonaro, who was in Dallas, United States, made the following statement: "It's natural, now that most are such a rioter. If someone asks the water formula, they will not know. They are useful idiots, imbeciles, who are being used as the maneuvering mass of a smart-assed minority that makes up the nucleus of many federal universities in Brazil". The second demonstration, on May 30, gathered about 1.8 million people in the streets of 190 cities in 26 states and DF, as well as 10 cities abroad.

In the 36 days between April 28 (two days before the minister announced the cuts) and June 2 (two days after the second national march in defense of universities), 115 memes that met the temporal and selection criteria were published on the "Bolsonaro's Supporters Group”. Those memes were in terms of language modalities, bimodal of the verb-visual type, and in thematic terms, focused centrally on higher education or the manifestations around universities. The memes were classified into six-time groups, which allowed us to observe that

(1) From April 28 to 30, the group published seven memes on the theme, then

(2) 25 memes in the first week of May and 
(3) 17 memes in second, rising to

(4) 50 memes in the week of May 15-21 - 30 of which were published only on the 15 th, \# $15 \mathrm{M}$ date - then production slowed, with

(5) Four memes in the week of 22 May 28th and (6) 12 memes from May 29 to June 2.

This distribution of the corpus in the weeks allows us to infer that the group under analysis gave much more relevance to the manifestation of May 15 than to May 30, although the latter was more significant in terms of popular participation.

All memes were inserted in a project created in the software NVivoPRO. For sorting the data, each text was named like this: "month-day.number" (for example, text 5-15.7 would have been the seventh meme published on May 15). Nodes were created for data coding in four analytical categories, considering the nature of the data and its multimodality: discursive strategy, intertextuality, salience, and theme. The coding was done manually by reading each text on the software-coding screen. For coding in each category, the two language modalities in focus were considered, so it was not necessary to separate verbal and visual analysis categories.

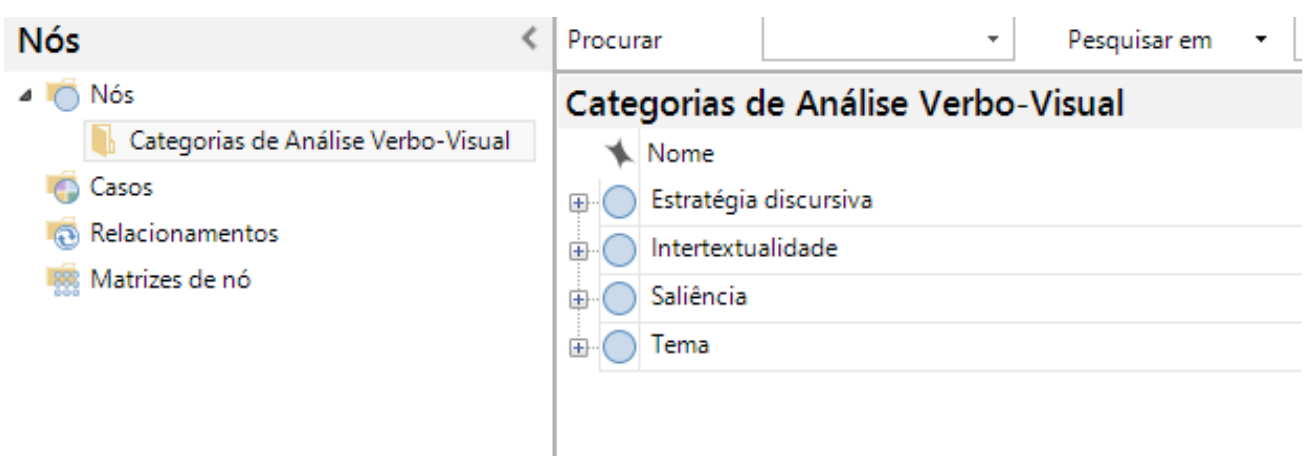

In the discursive strategy category, elements relevant to the construction of hate discourses were observed, according to the bibliography consulted: the opposition "we" / "them", de-personalization, the creation of the enemy and the representation by stereotypes:

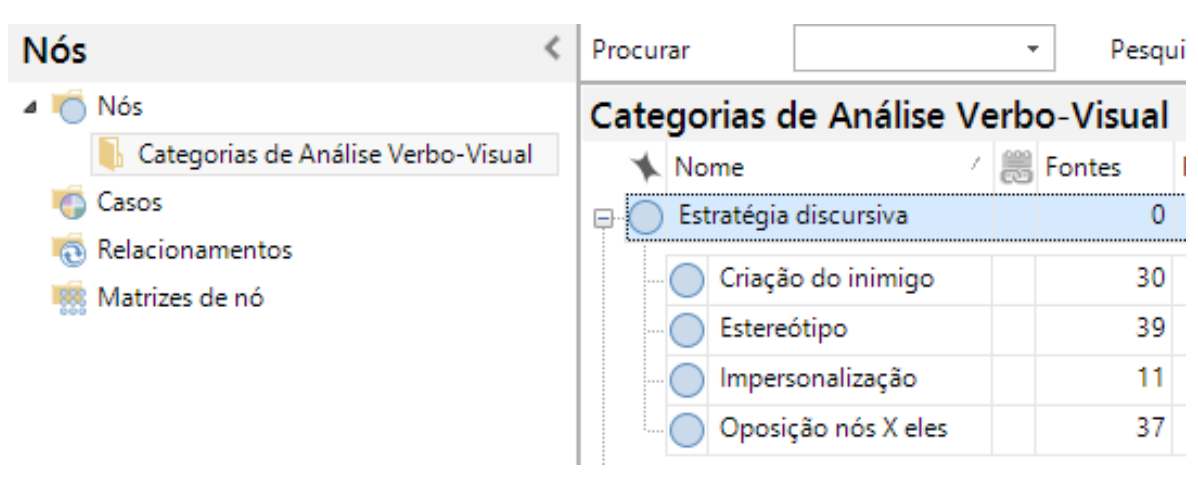

At this node, the most recurring cases in the corpus were the appeal to stereotypes and the 'we'/'they' opposition. In the case of stereotypes, negative representations 
of students were frequent, in many nudity images on university campuses, in decontextualized situations, and of teachers represented as indoctrinators. The 'we'/'they' opposition was built mostly on memes with more verbal content and with recurring opposition between the current government and the Workers' Party governments. The creation of the enemy was linked mainly to anti-communism, to icons of critical thinking like Paulo Freire and the political left. Finally, de-personalization was usually built by identity between students, teachers, or left-wing activists and donkeys (see below).

As it is possible to see by the composition of the corpus with 115 texts and the numbers expressed in the table, there were cases in which more than one discursive strategy coding was required. An example is the following meme:

\section{Meme 5-11-01}

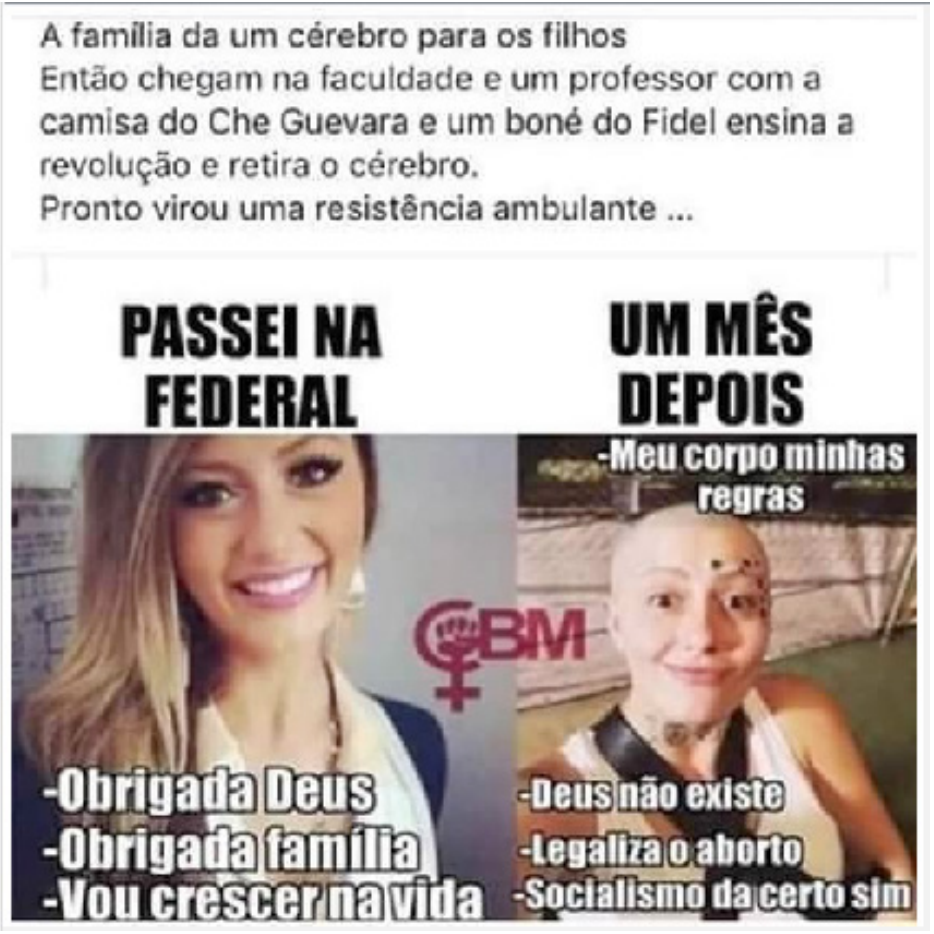

In this meme, there is the doctrinal teaching stereotype, linked to a specific image evoked in the physical description present in the verbal text at the top of the meme. Another central stereotype in the meme is that of the female figure deemed desired or appropriate, disciplined according to the norms of the church, the family, and the capitalist system of production and labor, in opposition to the female figure considered misfit, outside the aesthetic standards appropriate to the previous representation, irreverent. This simplified opposition of absolute opposites is characteristic of memetic language, which facilitates the apprehension of opposing discourses by clouding any complexity. Thus, it represents either an absolute positive identity, linked to specific aesthetic standards of presentation, to God, the family, and the capitalist meritocracy of "growing up in life", or the contrary absolute negative identity of church negation, 
abortion advocacy, and of socialism. The juxtaposed stereotypes then reinforce the 'we'/'them' opposition as well as the enemy's construction, with a unique appeal to fear in this case, as it emphasizes the possibility that one of 'us' becomes a 'from them'.

In the intertextuality coding node, the intertextual relations built on verbal or imaginary features of the analyzed memes were mapped. The essential feature in this category was the relationship with banners and posters displayed in the demonstrations in defense of universities. In these cases, the intertextual attribution mainly fulfilled the task of disqualifying students, teachers, and protesters; as they focused on bands that contained deviations from the standard norm of the Portuguese language as a form of ridicule the demonstration and its participants. Intertextual references to social networks were also recurring, with replication of content from Facebook itself or Twitter in the form of captured images, and intertextual relations with online newspapers, taken to recall cuts in resources of previous governments, to applaud the decisions of Bolsonaro's ministry or to disqualify the academic community. Another relevant intertextual aspect is the replication of images from one meme to another.

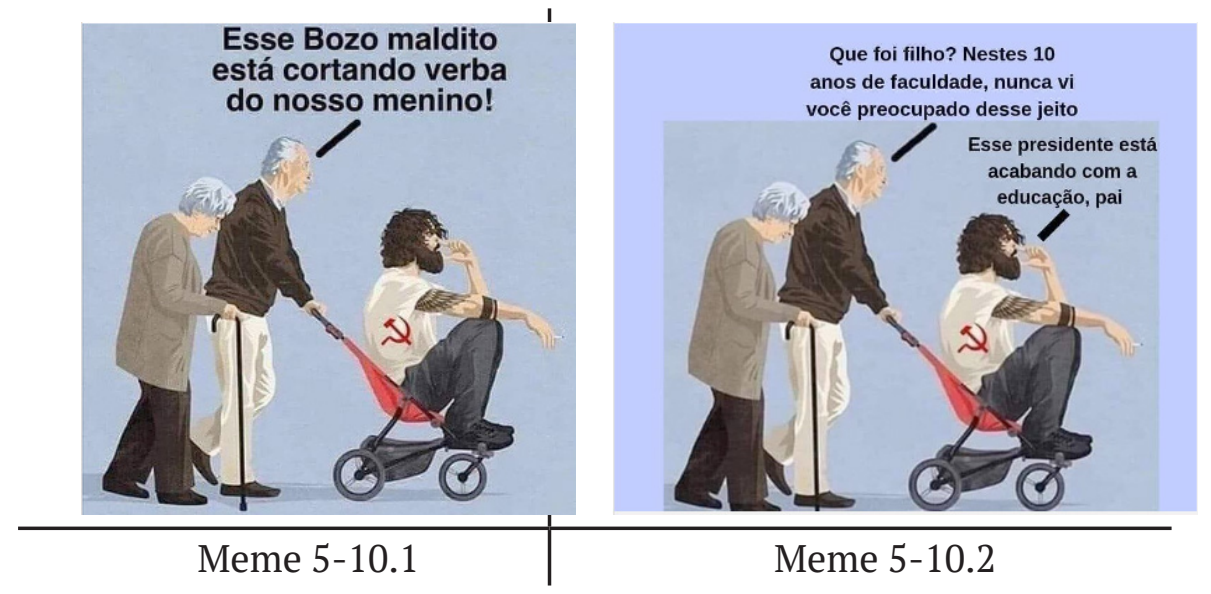

... or thematic replication between memes:

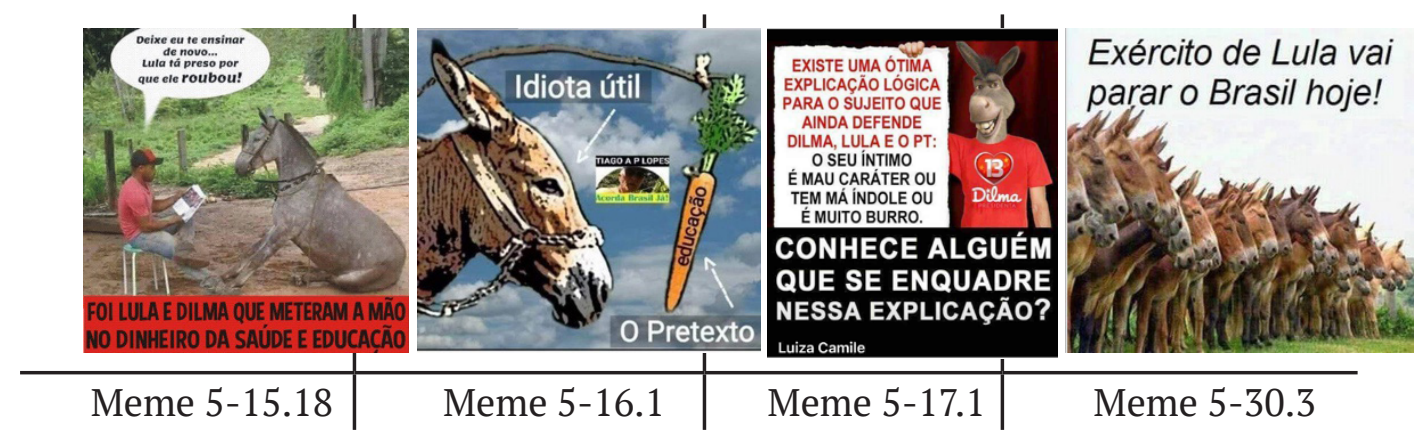

The salience coding nodes show the most prominent visual element in memes, in this case, written texts. Verbal texts are in a prominent position, for example, when 
banners in manifestations and other texts from social networks and newspapers are intertextually articulated. Other noteworthy elements are the protesters, often in demoralizing photographs, often comparative of conduct between pro-government marches and pro-education marches, or students in scenes of nudity or drug addiction, as also commented above.

Finally, in the theme category, the central subthemes for approaching the theme of higher education or the manifestations in the corpus memes were coded. The most recurring theme, in more than 30 of the memes, was the link between the Workers' Party and the demonstrations in defense of universities. This theme was almost always built through photographs of Lula Livre banners, CUT flags, and other symbols. In such cases, the effect was a disconnection between the manifestations and the problem of investments in higher education, reducing the debate to the right-left political polarization. Here are some examples from May 15:

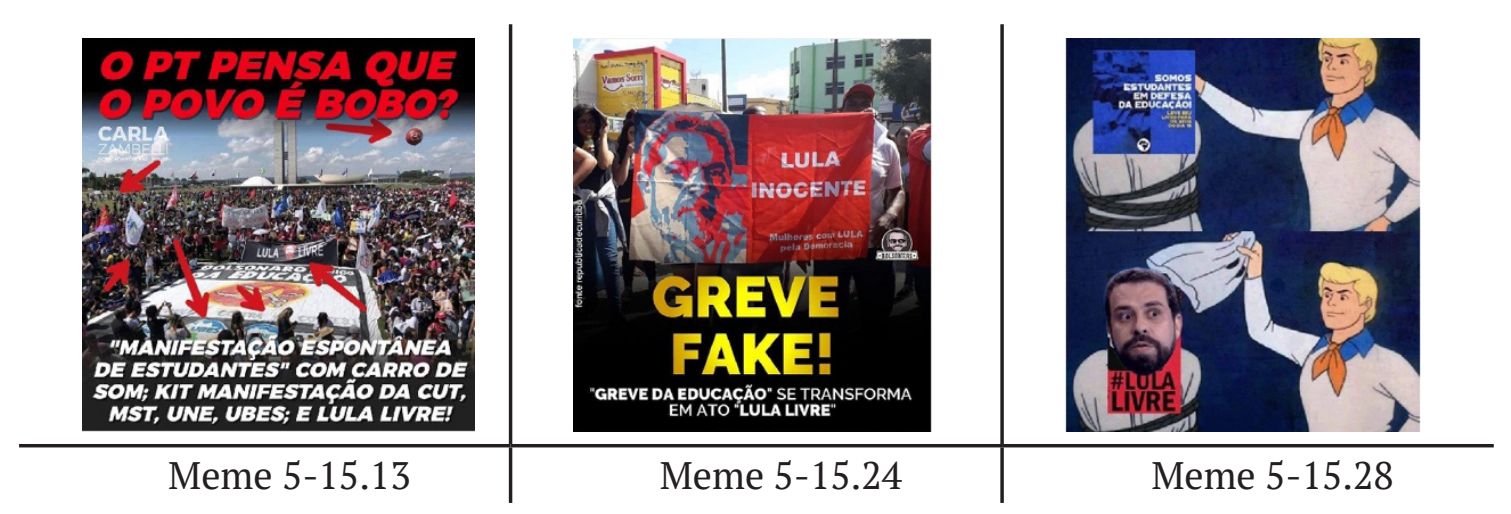

Other common themes in the corpus are irony to the very idea of demonstration or strike, nudity presented as a moral problem, justification or explanation about cuts in education, alleged student indoctrination, disqualification of knowledge in social and human sciences and the comparison between the demonstrations in favor of universities (associated with disorder) and those pro-Bolsonaro's government.

\section{FINAL CONSIDERATIONS}

This first approximation to the corpus of memes collected in the most significant support group for Bolsonaro on Facebook, in the range relevant to the specific theme of this article, reveals the disqualification of university institutions and their actors through ironies, negative associations including stereotypes, simplification of debate to the shallower. Students are often associated with nudity as immorality, professors of indoctrination and ridicule, protesters of ignorance, or bad character. Political debate is reduced to extreme left-right polarization, with the criminalization of the left and the fiction of the communist threat taken as enemy-building strategies. By emphasizing hate, the group avoids any discussion on the issue of the cuts themselves and their dire consequences for public higher education in Brazil.

In the best Bolsonarist's style, joking is the easiest way to avoid serious debate 
on any topic. Therefore, the threats in the field of education and science advance. After the demonstrations, there is the rubble: next to the universities that already announced they could not maintain themselves until the end of the year. In August, the National Council for Scientific and Technological Development - CNPQ informed the suspension of new fellows' appointment, which affected over more than 45,000 researchers in the country, according to CNPq itself. The agency's scholarships were paid in September. However, there was a threat of suspension of all scholarships in effect from the October payment, threatening the very maintenance of the lives of students who depend on this commitment, as they have maintained the exclusivity of paid research activity - a requirement to be a scholarship holder. More than 80,000 scholarships are threatened. On September 2, the Higher Education Personnel Improvement Coordination, CAPES, announced the cut of a further 5,613 postgraduate research fellowships, adding to the 6,198 blocked in the first semester. In less than seven months of Bolsonaro's management, the agency has cut 11,811 scholarships.

In 2019, Capes had R \$ 819 million contingent, representing 19\% of the amount previously authorized for its annual budget. For 2020, resources will fall by half, from $\mathrm{R} \$ 4.25$ billion in 2019 to $\mathrm{R} \$ 2.20$ billion in 2020. For the CNPq, which bitter deficit of 330 million in 2019, the budget for 2020 is 962 million, which does not even cover the payroll of the agency's current scholarships.

FUNDING: This research received no external funding.

CONFLICT OF INTEREST: The authors declare no conflict of interest.

ACKNOWLEDGEMENTS: We would like to thank the Radical Right Research International Network (RIN), from which this work in part. We also thank professor Carolina Lopes Araújo.

\section{REFERENCES}

Ballestrin, Luciana. 2018. "Desafios à democracia e as experiências do Sul Global.” Keynote Speech at $4^{o}$ Simpósio Nacional sobre Democracia e Desigualdade. Brasília, Brasil.

Barbosa, Muryatan. 2018. "Desafios à democracia e as experiências do Sul Global.” Keynote Speech at $4^{o}$ Simpósio Nacional sobre Democracia e Desigualdade. Brasília, Brasil.

Benesch, Susan. 2012. “Dangerous Speech: A Proposal to Prevent Group Violence.” World Policy Journal XXIX/3. Retrieved November 20, 2019 (https://worldpolicy. org/wp-content/uploads/2016/01/Dangerous-Speech-Guidelines-Benesch-January-2012.pdf).

Brugger, Winfried. 2007. "Proibição ou proteção do discurso do ódio? Algumas observações sobre o direito alemão e o americano.” Direito Público 4(15): 117-136.

Chagas, Viktor, Fernanda Freire, Daniel Rios and Dandara Magalães. 2017. “A política dos memes e os memes da política: proposta metodológica de análise de conteúdo de memes dos debates eleitorais de 2014.” Intexto 38 (1): 173-196.

Dawkins, Richard. 2001. O gene egoísta. Belo Horizonte: Itatiaia. 
Fausto, Boris. 1998 “Ensaio bibliográfico: a interpretação do nazismo, na visão de Norbert Elias.” Mana 4 (1): 141-152.

Freitas, Riva and Matheus Castro. 2013. "Liberdade de Expressão e Discurso do Ódio: um exame sobre as possíveis limitações à liberdade de expressão." Sequência 34(66): 227-352. http://dx.doi.org/10.5007/2177-7055.2013v34n66p327

Gagliardone, Iginio, Danit Gal, Thiago Alves nad Gabriela Martinez. 2015. Countering online hate speech. Unesco Publishing. Retrieved November 20, 2019 (https:// www.researchgate.net/publication/284157227).

Junqueira, Antolo. 2016. "Os memes e sua apropriação pelo marketing digital." Signos do Consumo 8(2): 19-29. https://www.bing.com/search?q=junqueira\%2C+a.+h.+os+memes

Kaysel, André. 2018. "Desafios à democracia e as experiências do Sul Global.” Keynote Speech at $4^{\circ}$ Simpósio Nacional sobre Democracia e Desigualdade. Brasília, Brasil.

Silva, Andréa. 2018. "Memes, educação e cultura de compartilhamento nas redes sociais." Artefactum 17(2): 1-19. http://artefactum.rafrom.com.br/index.php/artefactum/article/view

Silva, Rosane, Andressa Nichel, Anna Clara, Lehmann Martins and Carlise Borchardt. 2011. "Discursos de ódio em redes sociais: jurisprudência brasileira." Revista Direito GV 7(2): 445-465. http://bibliotecadigital.fgv.br/ojs/index.php/revdireitogv/article/view

Waldron, Jeremy. 2017. "Dignity and defamation: the visibility of hate." Harvard Law Review 123 (7): 1597-1654.

\section{BIOGRAPHICAL NOTE}

Viviane de Melo Resende is professor of Linguistics at the University of Brasilia, Brazil.

Yara Martinelli is International Relations fellow at the University of Brasilia, Brazil.

Ernani Viana Saraiva is professor of Management at the Fluminense Federal University, Brazil.

OPEN ACCESS: This article is distributed under the terms of the Creative Commons Attribution Non-commercial License (CC BY-NC 4.0) which permits any non-commercial use, and reproduction in any medium, provided the original author(s) and source are credited. 
